\title{
BRDT Gene
}

National Cancer Institute

\section{Source}

National Cancer Institute. BRDT Gene. NCI Thesaurus. Code C106460.

This gene plays a role in both chromatin remodeling and spermatogenesis. 